\title{
Investigation of mycotoxin residues in poultry feeds by LC MS/MS method
}

\author{
Nihayet Fadime YALÇIN ${ }^{1}$, Mehmet Kürşat IŞIK² ${ }^{2}$ Tülay AVCI ${ }^{1}$, Halis OĞUZ \\ Tuncay YURDUSEVEN ${ }^{4}$
}

\begin{abstract}
${ }^{1}$ Konya Veterinary Control Institute, Toxicology Laboratory; ${ }^{2}$ Food and Agriculture University, R\&D Laboratory; ${ }^{3}$ Selçuk University, Faculty of Veterinary Medicine, Department of Pharmacology and Toxicology, Konya; ${ }^{4}$ Izmir Food Control Laboratory Directorate, Mycotoxin Laboratory, İzmir, Turkey.
\end{abstract}

\begin{abstract}
Summary: In this study, it was aimed to determine the levels of mycotoxin contamination in poultry feeds in Konya, Afyonkarahisar, Aksaray and Nigde which constitutes $26.2 \%$ of the poultry production in Turkey. For this purpose a total of 73 readyto-consume poultry feed samples from poultry farms in four provinces were collected. A general screening in feeds was performed in terms of mycotoxin presence and contamination levels. Samples were analyzed for aflatoxin $\mathrm{B}_{1}$, ochratoxin A, zearalenone, T-2 toxin, HT-2 toxin, fumonisin and deoxynivalenol levels by LC-MS/MS multi-mycotoxin method. The levels of different mycotoxins in feeds obtained from poultry farms, the proportion of positive samples and the percentage of presence in the feeds were compared in terms of maximum residue limit (MRL). It was concluded that the feeds were found to be contaminated with low rates of mycotoxins, in terms of mycotoxin types and levels in the regions screened. However, the exceeded rates were found only $1 \%$ for aflatoxin $B_{1}(\geq 5 \mathrm{ppb})$ in poultry feeds according to communique on undesirable substances in animal feed (RG 2014/11) while other mycotoxins were below the MRL.
\end{abstract}

Keywords: Contamination, LC-MS/MS, mycotoxins, poultry feed.

\section{LC MS/MS metodu ile kanatlı yemlerinde mikotoksin varlığının araştırılması}

Özet: Bu çalışma ile Türkiye'nin kanatlı üretiminin \%26.2'sini oluşturan Konya, Afyonkarahisar, Aksaray, Niğde illerindeki kanatlı yemlerini kontamine eden mikotoksin düzeylerinin tespit edilmesi amaçlanmıştır. Bu amaçla dört ildeki kanatlı işletmelerindeki tüketime hazır kanatlı yemlerinden toplam 73 adet numune toplanmıştır. Yemlerin mikotoksin varlı̆̆ı ve bulaşma seviyeleri yönünden genel bir taraması yapılmıştır. Numuneler sıvı kromotografisi/kütle kütle spektrofotometri (LC-MS/MS) cihazı ile çoklu mikotoksin metodu ile aflatoksin $\mathrm{B}_{1}$, okratoksin A, zearalenon, fumonisin, deoksinivalenol, T-2 toksin ve HT-2 toksin analiz edilmiştir. Kanatlı işletmelerinden elde edilen yemlerde farklı mikotoksin seviyeleri, pozitif örneklerin oranı ve yemlerdeki yüzde oranları, maksimum kalıntı limiti (MRL) açısından karşılaştırıldı. Taranan bölgedeki mikotoksin tip ve seviyeleri açısından, kanatlı yemlerinin mikotoksinlerle düşük düzeyde kontamine edildiği sonucuna varılmıştır. Ancak, yemlerde istenmeyen maddeler tebliği'ne göre (RG 2014/11) yasal limiti aşan \%1 oranı ile sadece aflatoksin $B_{1}(\geq 5 \mathrm{ppb})$ hariç diğer mikotoksinlerin MRL'in altında olduğu belirlenmiştir. Anahtar sözcükler: Kanatlı yemi, kontaminasyon, LC-MS/MS, mikotoksin.

\section{Introduction}

Mycotoxins are a large group of toxins produced by moulds and they can be very toxic for animals, plants and humans. Mycotoxins occur particularly in regions or countries with climates of high temperature and humidity or where there are poor crop harvesting and storage conditions, which encourage mould growth and mycotoxin development (25). The toxic effects of mycotoxins are mainly on liver and they cause teratogenic, mutagenic, immunosuppressive, carcinogenic, cytotoxic, neurotoxic, nephrotoxic and oestrogenic effects $(3,21)$. These toxins may show no clinical symptoms unless they are with secondary bacterial infections and high rate of mortality. In this case, determination of economic losses by the ingestion of contaminated feed is difficult in commercial livestock production $(21,26)$. The larger problem is contaminated animal products that potentially threat the public health. Therefore, the toxin must be determined by analysis in feeds (8). Although, there are some difference according to country and regions, most dangerous mycotoxins in poultry feeds are aflatoxins (AFL) produced by Aspergillus, ochratoxin A (OTA) produced by Penicillium and Aspergillus spp and deoxynivalenole (DON), zearalenone (ZEA), T-2 toxin and fumonisin (FUM) produced by Fusarium $(6,16)$. 
AFL are a major concern in poultry production because of serious economic losses. The toxicity of AFL in poultry has been widely investigated by determining their teratogenic, carcinogenic, mutagenic and growth inhibitory effects (20). The most important source of AFL is corn, peanut meal, cottonseed meal, and feeds with high energy levels such as cereal grains, corn gluten, soya products, sunflower seeds, cotton seeds, palm kernel and dried coconut (22). OTA toxins are known as nephrotoxic and found relatively in cooler climates and in grains and products commonly (32). ZEA is a mycotoxin its chemical structure resembling estrogens and has estrogenic effect in animals (6). Fumonisins ( $\mathrm{FB}_{1}$ and $\left.\mathrm{FB}_{2}\right)$ are non-genotoxic carcinogens according to animal species, and have neurotoxic, hepatotoxic, nephrotoxic, immunosuppressive effects; they also cause growth retardation and liver cancers (17). Trichothecenes (T-2 and HT-2 toxins) are secondary metabolites of Fusarium, Stachybotrys, Trichothecium, Kerticimosporium, Cephalosporium ve Cylindrocarpen. T-2 toxin is an important mycotoxin produced by Fusarium and reported in low rates (less than $10 \%$ ) in forage samples. DON is the most common mycotoxin in food and feed (6).

In this study, it was aimed to determine the contamination of mycotoxins which have toxicological and economical importance in poultry feeds in Konya and the surrounding provinces (Afyonkarahisar, Aksaray and Nigde) which constitutes $26.2 \%$ of the poultry production in Turkey. Mycotoxin analyses are usually performed by chromatographic methods (TLC, HPLC, and LC-MS). However, in recent year rapid development of the LC MS/MS system has enabled us to take the multimycotoxin residue analyses (30). Performing a multimycotoxin screening by LC-MS/MS method; and the scarcity of similar studies with HT-2 detection in Turkey shows the importance of this study.

\section{Materials and Methods}

Sampling: Poultry feed samples, which are ready-toconsume, were collected from poultry farms in Konya, Afyonkarahisar, Aksaray and Nigde provinces. In this study the samples were collected from laying chicken farms between March and June 2014. Two $\mathrm{kg}$ of feed were obtained from different points of feed batch in order to represent the masses while the feeds were being distributed to animals. The samples were collected from different poultry farms on different days according to the "Official Regulation on Sampling and Analysis Methods of Feed for Control" (24). Total number of laying poultry farms in the provinces studied are 184 (33). The number of samples collected in this study was calculated according to the statistical program Raosoft (Seattle, USA) (23) with $90 \%$ confidence interval and $10 \%$ tolerance of error. A total of 73 samples were collected and taken in dark plastic bags, brought to the laboratory after being wrapped with the stretch film in cold conditions.

Sample preparation and clean-up procedures: Homogenization and extraction were performed for each of feed samples (29). Reagent-1, which was from ZV1030-0200-55 LC MS/MS analysis set, was added to five $\mathrm{g}$ of sample and vortexed for $30 \mathrm{sec}$. Then, reagent- 2 was added and also mixed for two min; and then centrifuged for five min at $4000 \mathrm{rpm} .5 \mathrm{ml}$ was taken from upper phase and transferred into a tube and evaporated under nitrogen. Then, reagent-3 was added into the tube, solved and filtrated through a $0.45 \mu \mathrm{m}$ filter and put into LC MS/MS. Reagents (R1, R2 and R3) were obtained from Zivak Technologies ${ }^{\circledR}$, Turkey.

Analysis: Extracts were stored in amber colored vials in a freezer until analysis. Feed samples were analyzed for AFL B $B_{1}$, OTA, ZEA, T-2 Toxin, HT 2 toxin, FUM and DON levels by LC MS/MS multi-mycotoxin method. Analysis was performed by LC MS/MS (Zivak, ZV-103402MA-Mobil Phase A, ZV-1034-02MB-Mobil Phase B, $1800 \mathrm{~V}$ detector, 0,20 mL/min, ZV-1034-02C1 150x2 mm, HPLC Column, 50 psi API Nebulising gas pressure, $350{ }^{\circ} \mathrm{C}$ drying gas temperature, 35 psi drying gas pressure, 0,5 min scanning time). Validation parameters were used as performance criteria for method validation (11). Validation parameters assessed were, linearity, recovery, limit of detection (LOD), limit of quantification (LOQ), repeatability (intra-day precision; RSDr), reproducibility (inter-day precision; RSDR) and specificity (Table 1). The multi-mycotoxin analytical method optimized for TMR was validated using spiked blank sample. The validation experiments that were used to calculate the LODs and LOQs were utilized also to calculate the recovery of the method. Recovery was carried out by spiked samples at three different levels, by repeating 6 times in different days for each level. Calculation of LOD and LOQ;

Limit of detection $(\mathrm{LOD})=3 \mathrm{X}$ Standard deviation Limit of quantification $(\mathrm{LOQ})=10 \mathrm{X}$ Standard deviation

Linearity was evaluated using matrix matched calibration curves, by spiking blank samples at six concentration levels for TMR. For specificity, TMR samples, which were known not to contain multi-mycotoxin, were analyzed; and no deviations were seen in the time of peak output when the standards added. Both repeatability and reproducibility were carried out by spiked samples at six different levels in different days. The levels of different mycotoxins in poultry feeds obtained from laying chicken farms, the proportion of positive samples, the percentage of presence in the feeds and the exceeded rates according to RG (2014/11) (25) were compared in terms of maximum residue limit (MRL) values. 
Table 1. Intra-day repeatability (RSDr), inter-day reproducibility (RSDR) expressed as recovery (R\%), coefficients of determination $\left(\mathrm{R}^{2}\right)$, LOD and LOQ obtained for each mycotoxin.

Tablo 1. Her bir mikotoksin için elde edilen tekrarlanabilirlik (RSDr), tekrar üretilebilirlik (RSDR), geri kazanım (\%R) ve korrelasyon katsayısı $\left(\mathrm{R}^{2}\right)$, LOD ve LOQ.

\begin{tabular}{l|c|c|c|c|c|c}
\hline $\begin{array}{l}\text { Method; } \\
\text { ZV-1030-500-55 LC-MS/MS }\end{array}$ & $\begin{array}{c}\text { LOD } \\
(\mathrm{ppb})\end{array}$ & $\begin{array}{c}\text { LOQ } \\
(\mathrm{ppb})\end{array}$ & $\begin{array}{c}\text { Coefficients of Determination } \\
\mathrm{R}^{2}\end{array}$ & $\begin{array}{c}\text { Recovery (R\%) } \\
\text { RSDr } \\
\%\end{array}$ & $\begin{array}{c}\text { RSDR } \\
\%\end{array}$ \\
\hline AFL B1 & 0.3 & 1 & 0,9931 & 98.89 & 6,81 & 4,49 \\
ZEA & 5 & 15 & 0,9979 & 100.39 & 2,46 & 3,72 \\
DON & 25 & 75 & 0,9996 & 97.29 & 11,02 & 7,67 \\
FB1 & 30 & 100 & 0,9871 & 92.46 & 8,22 & 11,07 \\
FB2 & 30 & 100 & 0,9984 & 89.437 & 11,4 & 11,15 \\
OTA & 0.5 & 1.25 & 0,9926 & 97.36 & 9,16 & 8,00 \\
T-2 toxin & 30 & 100 & 0,9984 & 100.49 & 3,15 & 2,74 \\
HT-2 toxin & 30 & 100 & 0,9994 & 100.52 & 2,84 & 1,24 \\
\hline
\end{tabular}

Table 2. Mycotoxin prevalence in poultry feeds according to the provinces and exceeded rates according to "communique on undesirable substances in animal feed" (RG 2014/11) (25).

Tablo 2. İllere göre kanatlı yemlerindeki mikotoksin yaygınlığı ve "yemlerde istenmeyen maddeler tebliği" (RG 2014/11) limitlerini aşma oranları (25).

\begin{tabular}{|c|c|c|c|c|c|c|}
\hline \multirow{2}{*}{ Mycotoxin } & Provinces & Afyonkarahisar & Aksaray & Konya & Nigde & TOTAL \\
\hline & $\mathrm{n}$ & 16 & 11 & 33 & 13 & 73 \\
\hline \multirow{3}{*}{ AFL B $B_{1}$} & TED;s & 4 & 3 & 14 & 2 & 23 \\
\hline & $(\%)$ & 5.5 & 4.1 & 19.2 & 2.7 & 31.5 \\
\hline & $\geq 5 \mathrm{ppb}^{*}$ & 0 & 1 & 0 & 0 & 1 \\
\hline \multirow{3}{*}{ OTA } & TED;s & 11 & 1 & 21 & 1 & 34 \\
\hline & $(\%)$ & 15.1 & 1.4 & 28.8 & 1.4 & 46.6 \\
\hline & $\geq 100 \mathrm{ppb}^{*}$ & 0 & 0 & 0 & 0 & 0 \\
\hline \multirow{3}{*}{$\mathrm{FB} 1+\mathrm{FB} 2$} & TED;s & 13 & 10 & 30 & 13 & 66 \\
\hline & $(\%)$ & 17.8 & 13.7 & 41.1 & 17.8 & 90.4 \\
\hline & $\geq 20.000 \mathrm{ppb}^{*}$ & 0 & 0 & 0 & 0 & 0 \\
\hline \multirow{3}{*}{ DON } & TED;s & 3 & 0 & 2 & 2 & 7 \\
\hline & $(\%)$ & 4.1 & 0 & 2.7 & 2.7 & 9.6 \\
\hline & $\geq 5.000 \mathrm{ppb}^{*}$ & 0 & 0 & 0 & 0 & 0 \\
\hline \multirow{3}{*}{ ZEA } & TED;s & 5 & 2 & 15 & 6 & 28 \\
\hline & $(\%)$ & 6.8 & 2.7 & 20.5 & 8.2 & 38.4 \\
\hline & $\geq 250 \mathrm{ppb}^{*}$ & 0 & 0 & 0 & 0 & 0 \\
\hline \multirow{3}{*}{$\mathrm{T}-2$} & TED;s & 0 & 0 & 0 & 0 & 0 \\
\hline & $(\%)$ & 0 & 0 & 0 & 0 & 0 \\
\hline & $30 \mathrm{ppb}^{* *}$ & 0 & 0 & 0 & 0 & 0 \\
\hline \multirow{3}{*}{ HT-2 } & TED;s & 1 & 0 & 1 & 0 & 2 \\
\hline & $(\%)$ & 1.4 & 0 & 1.4 & 0 & 2.7 \\
\hline & $30 \mathrm{ppb}^{* *}$ & 1 & 0 & 1 & 0 & 2 \\
\hline
\end{tabular}

n; Number of samples.

TED;s: Prevalence and percentage of toxins at detectable levels in LC MS/MS.

*: MRL: Maximum residue limit in RG.

**: LOD: Limit of detection.

n; Numune sayıs1.

TED;s: LC MS/MS'de tespit edilebilir düzeydeki toksinlerin yüzdesi ve sayısı.

*: MRL: RG'deki maksimum kalıntı düzeyi.

**:LOD: Tespit limiti.

\section{Results}

In this study, mycotoxin contaminations were investigated in poultry feeds collected from poultry farms in Konya, Afyonkarahisar, Aksaray and Nigde provinces (Figure 1). Samples were analyzed for AFL $B_{1}$, OTA, ZEA, DON, FB1+FB2, T-2 toxin and HT-2 toxin levels by LC MS/MS multi-mycotoxin method.
The most common mycotoxin was FB1+FB2 in the region (90.4\%) according to the results of the analyses (Figure 2). The presence rate was $46.6 \%$ for OTA, $38.4 \%$ for ZEA, $31.5 \%$ for AFL $B_{1}, 9.6 \%$ for DON and $2.7 \%$ for HT-2 toxin respectively. T-2 toxin was not determined at the detectable levels (Table 2). 


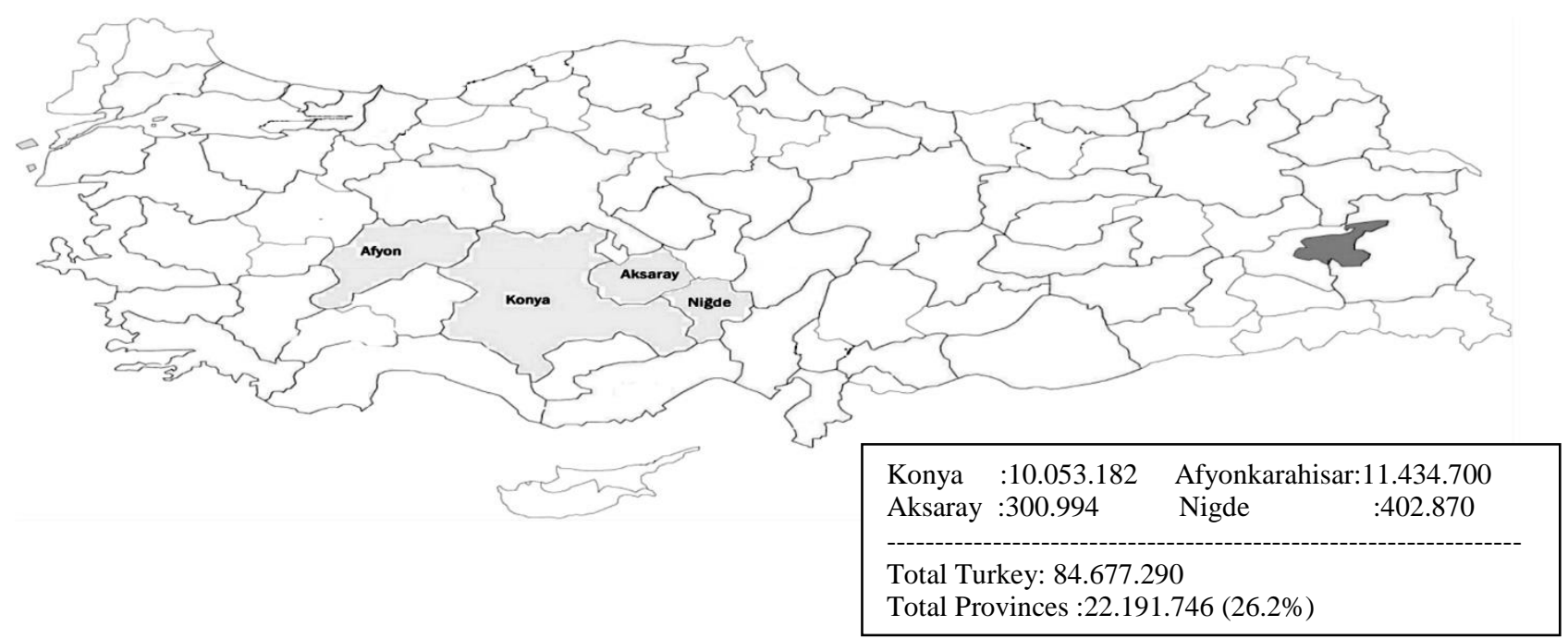

Figure 1. Provinces from which the samples were collected and the numbers of poultry (31).

Şekil 1. Kanatlı yemlerinin toplandığı iller ve kanatlı sayısı (31).

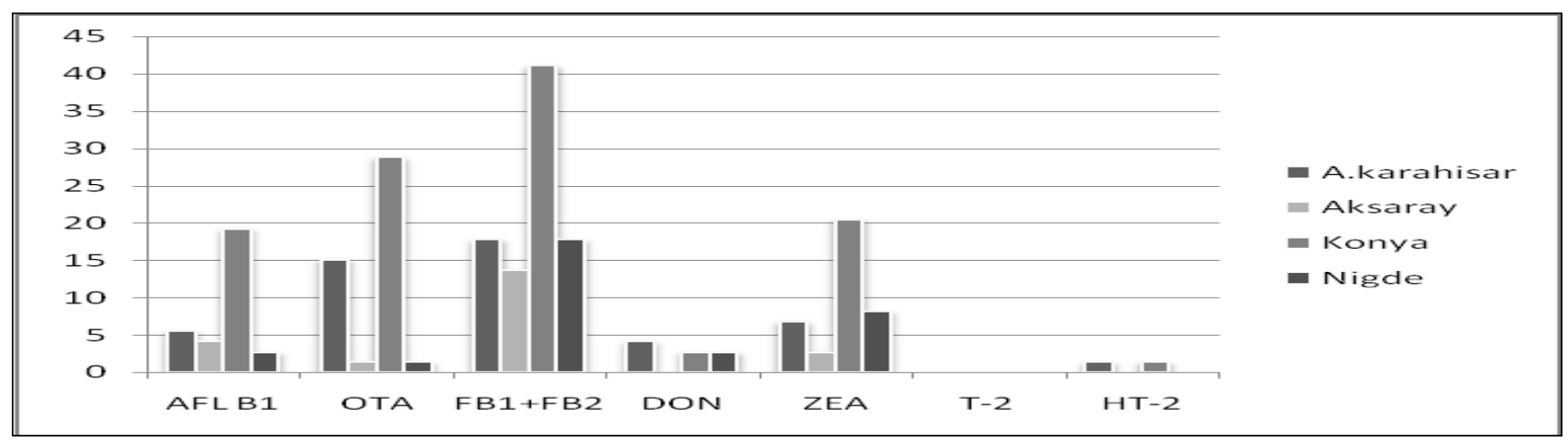

Figure 2. Mycotoxin rates in poultry feeds in provinces.

Şekil 2. İllerdeki kanatlı yemlerindeki mikotoksin bulunma oranları.

HT-2 and DON were found less than $10 \%$ in poultry feeds analyzed in terms of the prevalence of mycotoxins at the basis of provinces (Figure 1). Toxin levels were found not to exceed the MRL except AFL $B_{1}(1 \%)$ according to RG (2014/11) (25) in the entire region. No MRL was given for T-2 and HT-2 toxin in poultry feed. In this study, T-2 toxin was not detected in the samples while HT-2 toxin was found in two samples between 50 and 100 ppb level (Table 2).

\section{Discussion and Conclusion}

In this study, the most common mycotoxin was $\mathrm{FB}_{1}+\mathrm{FB}_{2}(90.4 \%)$ according to the results of multiple mycotoxins analyses for the presence of AFL $B_{1}$, OTA, ZEA, $\mathrm{FB}_{1}+\mathrm{FB}_{2}$, DON, T-2 and HT-2 toxins performed in poultry feed collected from poultry farms in Konya and surrounding three provinces. Fumonisin concentrations vary in feeds according to seasons (10), corn, corncontaining food are widely available for toxin production throughout the world (1). Greco et al. (14) analyzed mycotoxin contamination in poultry feed by ELISA and found fumonisin in all samples (mean $1.75 \mathrm{ppb}$ ) in Argentina. Demir (9), reported 94\% F. moniliforme contamination in 100 corn samples and fumonisin $\mathrm{B}_{1}$ was found in 52 samples and fumonisin $B_{2}$ in 25 samples in Samsun region. The presence of fumonisin in the present study is consistent with data from previous studies.

AFL $B_{1}(0-5 \mathrm{ppb})$ was found in 23 in the samples while $1 \%$ was exceeded the MRL. Nizamlioglu and Oguz (19), analyzed AFL in 72 feed and corn samples in Konya region by ELISA method and total AFL was found $71.1 \%$ in the samples and reported that four of them exceeded the MRL and 50\% were below 5 ppb. Dagasan and Ozen (7) investigated aflatoxin contamination in poultry and poultry feeds and found 67 of 70 samples were positive for AFL $B_{1}$ which was below MRL.

In this study, OTA was found in 34 samples at the rate of 46.6. Kaya et al. (15) investigated mycotoxin contamination in 51 feed samples (corn, soybean meal, sunflower meal, cottonseed meal) and found OTA in seven samples between 200 and 800 ppb. Martins et al. (18) analyzed OTA by HPLC method in 12 samples and 
found up to $2 \mathrm{ppb}$ by at the rate of $6.45 \%$ in the poultry feeds in a surveying study (2001-2004) in Portugal. Sherazi et al. (27) analyzed OTA in Pakistan and found the exceeded rate (EU; $100 \mathrm{ppb}$ ) were $38 \%$ in feeds and $31 \%$ in feedstuffs while confirmation were performed by HPLC-FLD. Surveying studies (2001-2004) made by ELISA reported that OTA contamination was $47.82 \%$ in feedstuffs and $27.27 \%$ in the poultry feeds in Turkey (32). Sonal and Oruc (28) investigated mycotoxin contamination in poultry feeds by ELISA method and found AFL B 1 (0.86 ppb), OTA (4.36 ppb), ZEA (78.64 $\mathrm{ppb}$ ), fumonisin (188 ppb) ve T-2 toxin (58.60 ppb) in Bursa region. Binder et al. (5) reported that DON, ZEA and $\mathrm{T}-2$ toxin were major contaminants in the feeds in Europe region, while DON, ZEA, fumonisin and AFL were common in Asia and the Pacific region. Abia et al. (2) found $\mathrm{DON}, \mathrm{FB} 1+\mathrm{FB} 2+\mathrm{FB} 3$, beta zearalenol in poultry feeds by LC-ESI-MS/MS method in Cameroon. Greco et al. (14) reported mycotoxin contamination at the rate of $90 \%$ including DON (mean $222 \mathrm{ppb}$ ), OTA (mean $5 \mathrm{ppb}$ and AFL (mean $2.69 \mathrm{ppb}$ ), while $86 \%$ ZEA (mean $50 \mathrm{ppb}$ ) and $78 \%$ T-2 toxin (mean $50 \mathrm{ppb).} \mathrm{Bilal} \mathrm{et} \mathrm{al.} \mathrm{(4)}$ analyzed broiler feeds in terms of mycotoxin contamination by HPLC and reported AFL (0-0.99 ppb) at the rate of $43 \%$ and ZEA $(0-20.87 \mathrm{ppb})$ at $86 \%$ while DON was not detected. The difference and prevalence of mycotoxin levels between our results and other researches performed by other researchers in poultry feed might be due to the difference of the feed contents, regional circumstances and/or analysis methods applied.

Thirteen countries determined the MRL for T-2 and HT-2 toxins around the world in food and feeds (12). According to this, maximum tolerable levels were $100 \mathrm{ppb}$ for T-2 toxin and $1000 \mathrm{ppb}$ for HT-2 toxin in Canada for poultry feeds by the reference of FAO (13). In this study, T-2 toxin were not found at the detectable levels and HT2 toxin levels were max $100 \mathrm{ppb}$; and it is understood that these levels could not affect the public and animal health when compared to other countries permissible levels.

According to the results of this study, it is understood that Fusarium, Penicillium and Aspergillus mold species were produced in poultry feeds depending on the content of feed and storing conditions. The provinces survived in this study, represent $26.2 \%$ of the poultry production in Turkey. The result of this study is considered to be hopeful for animal and public health in terms of MRL values. Although the presence of mycotoxins in poultry feed in the region is not a major threat in terms of economics, animal and public health, it should be careful in the supplying feedstuffs, during storage and consumption in terms of toxin production especially in poultry farms.

\section{Acknowledgements}

This work was supported by the Department of Agricultural Economy and Policy Research (TAGEMHSGYAD 14/AO5/PO4/69). The abstract of this study was presented as a poster in the $32^{\text {nd }}$ World Veterinary Congress, Istanbul, Turkey, 2015.

\section{References}

1. Abdel-Wahhab MA, Hassan AM, Amer HA, et al. (2004): Prevention of fumonisin-induced maternal and developmental toxicity in rats by certain plant extracts. $\mathbf{J}$ Appl Toxicol, 24, 469.

2. Abia WA, Simoa GN, Warthb B, et al. (2013): Determination of multiple mycotoxins levels in poultry feeds from Cameroon. Jpn J Vet Res, 6, 33-39.

3. Abrunhosa L, Moraless H, Soares C, et al. (2016): Review of mycotoxins in food and feed products in Portugal and estimation of probable daily intakes. Crit Rev Food Sci, 56, 2.

4. Bilal T, Aksakal DH, Sünnetci S, et al. (2014): Detection of aflatoxin, zearalenone and deoxynivalenol in some feed and feedstuffs in Turkey. Pak Vet J, 34, 459-463.

5. Binder EM, Tan LM, Chin LJ, et al. (2007): Worldwide occurrence of mycotoxins in commodities, feeds and feed ingredients. Anim Feed Sci Tech, 137, 265-282.

6. Cankırı B, Uyarlar C (2013): Place and importance of mycotoxins in dairy cattle nutrition. Kocatepe Vet J, 6, 57-69.

7. Dagasan O, Ozen N (2011): Aflatoxin, heavy metal and pesticide residue contents of some compound feeds produced in Turkey. Akdeniz Univ Ziraat Fak Derg, 24, 913.

8. Dalvi RR, Ademoyero AA (1984): Toxic effects of aflatoxin $B_{1}$ in chickens given feed contaminated Aspergillus flavus and reduction of the toxicity by activated charcoal and some chemical agents. Avian Disease, 28, 61.

9. Demir C (2002): An investigation presence of Fusarium moniliforme, fumonisin B1 and fumonisin B2 in corns grown in Samsun province. Trakya Üniv Fen Bil Enst Doktora Tezi, 84.

10. Dogan A, Tuzcu M (2001): Fumonizinler. Kafkas Univ Vet Fak Derg, 7, 237-244.

11. EURACHEM Guide (2014): Eurochem Guide. The Fitness for Purpose Analytical Methods. A Laboratory Guide to Method Validation and Related Topics. $2^{\text {nd }}$ edition. Available at https://www.eurachem.org/images/stories/ Guides/pdf/MV_guide_2nd_ed_EN. pdf. Accessed 17.04.2014.

12. European Food Safety Authority (EFSA) (2011): Scientific opinion on the risks for animal and public health related to the presence of T-2 and HT-2 toxin in food and feed. EFSA Panel on Contaminants in the Food Chain. EFSA Journal, 9, 2481.

13. FAO (Food and Agriculture Organization) (2004): Worldwide regulations for mycotoxins in food and feed in 2003. Available at http://www.fao.org/docrep/007/y5499e/ y5499e00. htm. FAO Food and Nutrition, 81, (Accessed 13 December 2014).

14. Greco MV, Franchi ML, Golba SLR, et al. (2014): Mycotoxins and mycotoxigenic fungi in poultry feed for food-producing animals. The Scientific World Journal. 
Available at http://dx.doi.org/10.1155/2014/968215. (Accessed 21 September 2014).

15. Kaya S, Yavuz H, Akkar F (1990): Mycotoxin residues in some oily seed meals. Vet J Ankara Univ, 37, 173-180.

16. Kaya S (2002): Mikotoksinler. Kaya S, Pirinçci İ, Bilgili A. Veteriner Hekimliğinde Toksikoloji. 2. Baskı, 537-575, Medisan Yayınevi, Ankara.

17. Kriek NPJ, Kellerman TS, Marasas WFO (1981): A comparative study of the toxicity of fusarium verticilloides ( $F$. moniliforme) to horses, primates, pigs, sheep, and rats. Onderstepoort J Vet Res, 48, 129-131.

18. Martins HM, Almeida I, Camacho C, et al. (2012): A survey on the occurrence of ochratoxin A in feeds for swine and laying hens. Mycotoxin Res, 28, 107-110.

19. Nizamlığlu F, Oguz H (2003): Occurrence of aflatoxins in layer feed and corn samples in Konya province, Turkey. Food Addit Contam, 20, 654-658.

20. Oguz H, Kurtoglu V (2000): Effect of clinoptilolite on fattening performance of broiler chickens during experimental aflatoxicosis. Br Poult Sci, 41, 512-517.

21. Oguz H (2011): A review from experimental trials on detoxification of aflatoxin in poultry feed. Eurasian J Vet Sci, 27, 1-12.

22. Placinta CM, D'Mello JPF, MacDonald EK (1999): A review of worldwide contamination of animal feed with Fusarium mycotoxins. Anim Feed Sci Tech, 78, 21-37.

23. Raosoft (2015): Sample size calculator. Seattle, USA. Retrieved from Raosoft: Available at http://www.raosoft. com/samplesize.html. (Accessed 24 August 2016).

24. Resmi Gazete (a) (2011): Yemlerin Resmî Kontrolü İçin Numune Alma ve Analiz Metotlarına Dair Yönetmelik. 28155.

25. Resmi Gazete (b) (RG 2014/11) (2014): Yemlerde Istenmeyen Maddeler Tebliği (Communique on undesirable substances in animal feed).Veteriner Hizmetleri, Bitki Sağlı̆̆ 1 , Gida ve Yem Kanunu. 28977.

26. Santin E (2015): Understanding mycotoxins published on federal university of Parana, Brazil. Available at http://en.engormix.com/MA-mycotoxins/articles/ understanding-mycotoxins-t3428/p0.htm (Accessed 27 March 2015).
27. Sherazi STH, Shar ZH, Sumbal GA, et al. (2015): Occurrence of ochratoxin $A$ in poultry feeds and feed ingredients from Pakistan. Mycotoxin Res, 31, 1-7.

28. Sonal S, Oruc HH (2000): Natural mycotoxin level in mixed feed taken from poultry farm in Bursa province. YYU Vet Fak Derg, 11, 1-6.

29. Teşhiste Metot Birliği (2014): Farmakoloji ve Toksikoloji. Hayvansal doku, yem ve yem hammaddelerinde aflatoksin ve okratoksinin LC-MS/MS ile analizi metodu. Available at http://www.tarim.gov.tr/GKGM/Belgeler/Veteriner\%20 Hizmetleri/teshiste_metod_birligi_farmakoloji_ toksikoloji.pdf. (Accessed 25 February 2015).

30. Tiryaki O, Seçer E, Temur C (2011): Yemlerde mikotoksin oluşumu, toksisiteleri ve mikotoksin kalıntı analizleri. Anadolu J AARI, 21, 44-58.

31. Turkish Statistical Institute (TUIK) (2014): Available at http://www.tuik.gov.tr/HbGetir.do?id = 18851\&tbid $=6$. (Accessed 15 March 2015).

32. Yıldız G (2009): Determination of the contamination of the ochratoxine A in feeds and feedstuffs into the different animal enterprise in Turkey. Vet J Ankara Univ, 56, 131135.

33. Yumurta Üreticileri Birliği Verileri (Yum-Bir) (2013): Available at http://www.yum-bir.org/UserFiles/File/ yumurta-verileri 2013.pdf. (Accessed 24 August 2016).

Geliş tarihi: 04.11.2015 / Kabul tarihi: 29.08.2016

Address for correspondence:

Nihayet Fadime YALÇIN

Konya Veterinary Control Institute,

Toxicology Laboratory, Konya, Turkey. e-mail: nfadimeyalcin72@yahoo.com.tr nihayetfadime.yalcin@gthb.gov.tr 